\title{
THe Role OF Policy IN THE EXERCISE OF Discretion: A COMPARATIVE SEARCH FOR FAIRNESS
}

\author{
Friso Jansen ${ }^{1}$ \\ Birmingham City University, United Kingdom
}

\begin{abstract}
The executive in implementing the wishes of parliament is often faced with a problem of allocation. How to distribute limited resources and exercise the discretion afforded to the executive in such a way that this is both procedurally and substantively fair? The answer lies in the formulation of a policy. Through clear and transparent procedures citizens would be treated equally, therefore delivering administrative justice. Different countries, however, seem to prioritize different conceptions of fairness and equality. While in English administrative law the focus is placed on the need for a scrutiny of the individual circumstances of a claimant to avoid fettering discretion in Dutch administrative law the stress is placed on the claimant to prove he should be treated differently to the standard case envisaged in a policy document. The question becomes whether on closer inspection these theoretical differences in approach reveal differences in practical application. This paper will try to answer some of these questions based on a comparative reading of law and jurisprudence from both countries.
\end{abstract}

Keywords: discretion, policy rules, fairness.

Content: 1. Policy Rules in the Netherlands: The General Administrative Law Act Reviewed. 2. Fettering Discretion: Restraining Decision-Makers Through Development of the Common Law. 3. Auer Deference: A Striking Absence. 4. The Exercise of Discretion: Is Achieving Fairness an Impossible Dream?

\section{Policy Rules in the Netherlands: The General Administrative LaW Act REVIEWED}

Exercise of discretion by an administrative decision-maker to award a permit, give a subsidy, award benefits etc. is in many cases restricted through three overlapping mechanisms: the existence of policy promulgated by the decision maker, the existence of policy rules (beleidsregels) that provide detail on how the decision maker will apply the policy and the general principles of good administration (algemene beginselen van behoorlijk bestuur) that govern the exercise of discretion. The relationship between these three layers is complex and the way the judiciary evaluates the exercise of discretion is developing. The codification of policy rules in article 4:84 of the General Administrative Law Act (Algemene Wet

\footnotetext{
${ }^{1}$ Associate Director, Center for Law Science \& Policy, Birmingham City University. Friso.Jansen@bcu.ac.uk
} 
Bestuursrecht) (GALA) has led to a large increase in their use. The GALA requires that a decision maker follows its policy rules in all cases, thereby treating everyone in accordance with the principle of equality — one of the general principles of good administration. However, if maintaining the policy rules in an individual case leads to consequences for the applicant that are disproportionate in relation to goals of the policy rules the decision maker must deviate from the policy rules. ${ }^{2}$ This is described as the inherent power to deviate (inherente afwijkingsbevoegdheid). The circumstances in which this deviation can occur are strictly prescribed; the applicant would need to make a very compelling case that his or her circumstances are exceptional. The courts give the decision maker a wide latitude in deciding whether a case is so exceptional as to warrant the use of the inherent power to deviate from the policy rules. ${ }^{3}$ Recently, however, the Administrative Jurisdiction Division of the Council of State (Afdeling Bestuursrechtspraak van de Raad van State) has been more exacting and required the decision-maker to give a detailed motivation about why they did not allow an exception, even though the case of the applicant was not one in which the policy rules envisaged the discretion to award a permit would be exercised. ${ }^{4}$

This increasing intensity of judicial scrutiny is interesting, and shows a shift in the appreciation of the role of the various powers in the trias politica. Traditionally the judiciary would be wary of encroaching upon the exercise of executive discretion, fearing that in this way they would disrupt the democratic process. ${ }^{5}$ The idea of Wednesbury Unreasonableness is comparable albeit not identical.

Over the years this traditional idea was replaced by the notion that the legislator was leaving more and more powers to the discretion of the executive, thereby reducing the political legitimacy of the decisions of the executive. In addition, the increasing number of decisions taken by the executive, a result of the increasing reach of the welfare state, meant that fewer and fewer decisions were subject to direct or indirect democratic control. In addition the legislator required the administrative judges to do more to make sure that disputes would be definitely resolved, rather than referring the decision back to the executive. ${ }^{6}$ The outcome of these various political and societal developments is that administrative judges strive to provide

\footnotetext{
${ }^{2}$ Art. 4.84 section 3 GALA.

${ }^{3}$ ECLI:NL:RVS:2000:AN6745,Administrative Jurisdiction Division of the Council of State (Sept. 26, 2000).

${ }^{4}$ ECLI:NL:RVS:2017:1314, Administrative Jurisdiction Division of the Council of State (May 17, 2017) with annotation AB 2017/270 H.E. Broring.

${ }^{5}$ Rolf Ortlep \& Wouter Zorg, Van Marginale Rechterlijke Toetsing naar Toetsing op Maat: Einde van een Geconditioneerde Respons? ARS AEQUi 20 (2018).

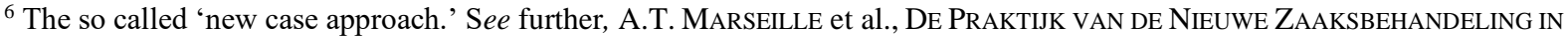
HET BESTUURSRECHT (2015).
} 
more support to citizens that challenge the exercise of discretion by decision-makers and more frequently than before try to encourage the executive to achieve substantive equality, by adequately considering all the individual circumstances of applicants. In this way, they push for decision-making that is more than mechanical application of policy rules but rather maatwerk, decisions that are made to fit each individual applicant.

\section{FetTERING Discretion: Restraining DeCision-Makers Through DEVELOPMENT OF THE COMMON LAW}

Fettering discretion would occur if a policy was inflexible and did not allow for exceptions in the exercise of discretion by an administrative decision-maker. Such a policy would be unlawful as the individual circumstances of an applicant could not be taken into account. Where in the Netherlands the GALA always allows decision-makers to depart from their policy rules if the circumstances warrant it, common law requires that decision maker states this explicitly in the policy to avoid a charge of fettering discretion. ${ }^{7}$ At first sight this might seem to imply that English administrative law values flexible decision-making that is tailored to individual circumstances of all applicants as fair, closely connected to the underlying principle of substantive equality of applicants. This would stretch the role of fettering discretion too far. Instead in English administrative law the legal certainty that the enactment of a policy brings and the consistent application of policy are equally prized as important elements of the rule of law. ${ }^{8}$ This tension between consistency to allow for legal certainty, and specificity to individual circumstances to achieve fairness is a known tension in public law. The way in which the courts try to balance these two aims is through requiring the decision-maker to have a good reason for departing from the policy. ${ }^{9}$ The quality of the reasons for departure, and here a closely parallel lies with the Dutch experience, is the main focus of judicial control.

The conceptual tree English judges use to justify a development of a ground of judicial review is of course the rule of law. A similar tendency can be observed in that the judiciary increasingly intensifies scrutiny by requiring the decision-maker to provide more compelling reasons, more extensive factual support, or a combination of these before certifying a decision as lawful.

\section{Auer Deference: A Striking AbSence}

\footnotetext{
${ }^{7}$ R. v. Hampshire CC ex p. W [1994] E.L.R. 460.

${ }^{8}$ R. (Alvi) v. Sec'y of State for the Home Dep't [2012] UKSC 33; R. v. Min. of Agric., Fisheries \& Food, ex p. Hamble (Offshore) Fisheries Ltd. [1995] 2 All E.R. 714.

${ }^{9}$ R. (Munjaz) v. Mersey Care NHS Trust [2006] 2 A.C. 148.
} 
An interesting aside is the striking contrast with the deference doctrines in the USA, where policy rules (regulations) that interpret the application of the law are shown deference by the court if the law is ambiguous and the interpretation by the executive in the regulation is not unreasonable. ${ }^{10}$ The reason that both England and The Netherlands do not know such a form of deference - policy rules that interpret the law do exist but they are not seen as in any way binding upon the court - is likely partly due to the different position of the executive. In the USA however, through the president the executive has direct democratic legitimacy, and through confirmation by the senate of key positions in the bureaucracy there is added democratic legitimacy for decision-makers.

\section{THE EXERCISE OF Discretion: IS ACHIEVING FAIRNESS AN IMPOSSIBLE DREAM?}

Both England and the Netherlands try to achieve the goal of fairness in tying the exercise of discretion by administrative decision-makers to the rule of law and allowing judicial scrutiny of their exercise. Starting from two very different historical starting points it becomes clear that the solutions to the problem of the tension between the general interest and the interests of the individual are strikingly similar. In both traditions increased judicial scrutiny has run parallel with a decrease in democratic legitimacy of the executive, compelling a need to protect the citizen against an overbearing state. The line between a valid rejection of a citizen as not falling within the rules and an oppressive decision that arbitrarily and therefore unlawfully withholds a benefit is one that is drawn over and over again. Recent jurisprudence shows that, against a backdrop of increasing Europeanisation, the free room for the executive to strike a bargain between the various interests at stake has been eroded. Deference to the executive has not disappeared but the executive faces increasingly critical scrutiny.

\section{LIST OF ABBREVIATIONS}

GALA - General Administrative Law Act (Algemene Wet Bestuursrecht)

\section{REFERENCE LIST}

\footnotetext{
${ }^{10}$ See Auer v. Robbins, 519 U.S. 452 (1997); Kisor v. Wilkie, 588 U.S.__ (2019). See also Chevron U.S.A., Inc. v. Natural Resources Defense Council, Inc., 467 U.S. 837 (1984); Mayo Found'n for Medical Science \& Research v. United States, 562 U.S 44 (2010); United States v. Mead Corp., 533 U.S. 218 (2001).
} 
A.T. Marseille et al., De PraktiJK VAn DE Nieuwe ZaAKsbehandeling in HeT BESTUURSRECHT

https://prettigcontactmetdeoverheid.nl/sites/default/files/documenten/BZK\%20NZB\%20Rapp ort\%20pdf.pdf

Auer v. Robbins, 519 U.S. 452 (1997).

Chevron U.S.A., Inc. v. Natural Resources Defense Council, Inc., 467 U.S. 837 (1984).

ECLI:NL:RVS:2000:AN6745, Administrative Jurisdiction Division of the Council of State (Sept. 26, 2000).

ECLI:NL:RVS:2017:1314, Administrative Jurisdiction Division of the Council of State (May 17, 2017).

General Administrative Law Act (Algemene Wet Bestuursrecht).

Kisor v. Wilkie, 588 U.S. (2019).

Rolf Ortlep \& Wouter Zorg, Van Marginale Rechterlijke Toetsing naar Toetsing op Maat: Einde van een Geconditioneerde Respons?' ARS AEQUI 20-25 (2018).

Mayo Found'n for Medical Science \& Research v. United States, 562 U.S 44 (2010).

R. v. Hampshire CC exp. W [1994] E.L.R. 460.

R. (Alvi) v. Sec'y of State for the Home Dep't [2012] UKSC 33.

R. v. Min. of Agric., Fisheries \& Food, ex p. Hamble (Offshore) Fisheries Ltd. [1995] 2 All E.R. 714.

R. (Munjaz) v. Mersey Care NHS Trust [2006] 2 A.C. 148.

United States v. Mead Corp., 533 U.S. 218 (2001). 